\title{
Barium and its Importance as an Indicator of (Paleo)Productivity
}

\author{
BIANCA T.P. LIGUORI, MARCELO G. DE ALMEIDA and CARLOS E. DE REZENDE
}

Laboratório de Ciências Ambientais, Centro de Biociências e Biotecnologia, Universidade Estadual do Norte Fluminense, Av. Alberto Lamego, 2000, Parque Califórnia, 28013-602 Campos dos Goytacazes, RJ, Brazil

Manuscript received on December 8, 2014; accepted for publication on June 18, 2016

\begin{abstract}
Barium $(\mathrm{Ba})$ is a trace element which occurs predominantly as barite mineral $\left(\mathrm{BaSO}_{4}\right)$ in the marine environment. Previous work suggests that barite concentrations are related to the organic carbon flux and marine biological debris in the water column suggesting a direct or indirect involvement in the marine biological cycling. In addition, barite has a high preservation rate $(\sim 30 \%)$ in sediments and it is less affected by early diagenesis than other proxies for productivity such as carbonates $(\sim 10 \%)$ and organic carbon $(\sim 1 \%)$, for example. Therefore, $\mathrm{Ba}$ is considered an excellent proxy for ocean (paleo)productivity. However, correlating barite to productivity involves some caveats. Specifically, the post-depositional formation of barite in oxic sediments can lead to Ba release into porewaters under anoxic conditions, which can form barite again under oxic conditions. This diagenetic formation is not correlated to export production as the seawater authigenic barite formed with decaying organic matter in the water column. Therefore, the main goal of this work is to briefly review the marine Ba cycle and highlight its importance for (paleo)productivity research.
\end{abstract}

Key words: barite, biogenic barium, (paleo)productivity proxy.

\section{INTRODUCTION}

Barium $(\mathrm{Ba})$ is a trace element found in igneous and sedimentary rocks in association with potassiumbearing minerals in the Earth's crust and it becomes available to the aquatic environment through chemical weathering of rocks and minerals. In the water column, Ba can occur in two forms: dissolved and particulate (Chow and Goldberg 1960). In rivers, it is mainly associated with suspended particulate matter (SPM) and tends to migrate in drainage basins associated with this matrix (Coffey et al. 1997). In estuarine environments Ba tends to desorp from the SPM. According to Coffey et al. (1997) the magnitude of Ba released into dissolved phase is dependent on the SPM supply and hydrodynamic conditions. This release is attributed to the process of exchange of the ion Ba, associated with the SPM, for other ions present in high

Correspondence to: Bianca Torres Pires Liguori

E-mail: bianca.liguori@hotmail.com

Carlos Eduardo de Rezende

E-mail: crezende@uenf.br 
concentrations in the marine environment which will lead to a progressive release of Ba from the SPM in the water column (Hanor and Chan 1977).

Through river runoff (continental input), Ba reaches the marine environment, where it will form barite $\left(\mathrm{BaSO}_{4}\right)$ or will be associated to other geochemical supports (e.g.: oxy-hydroxides, carbonates or aluminosilicates) (Fig. 1). In the marine environment $\mathrm{Ba}$ is mainly found in association with sulphate $\left(\mathrm{SO}_{4}\right)$, forming the mineral $\mathrm{BaSO}_{4}$. The flux and preservation of these crystals in sediments is expected to reflect the productivity in the water column as its formation in the water column is related to carbon export flux (Dymond et al. 1992). In marine sediments, Ba is also abundant in biogeochemical phases such as carbonates, organic matter, and biogenic silica (Robin et al. 2003), or associated with inorganic geochemical supports (e.g.: oxy-hydroxides of Fe and Mn, aluminosilicates) (Dymond et al. 1992, Pfeifer et al. 2001).

The formation of barite in the water column is influenced by different factors. This makes Ba a useful proxy for a wide range of processes in the marine environment providing insight into paleoenvironmental, hydrogeological and hydrothermal processes. Due to their chemical similarities (e.g., charge, ionic radius) cations like strontium, calcium, potassium, radium, lead or rare earth elements can substitute for Ba during the formation of barite (Guichard et al. 1979), which can lead to a reconstruction of the surrounding waters (Griffith and Paytan 2012).

Barite is one of the few minerals formed authigenically in the marine water column (Griffith and Paytan 2012) which is usually under saturation conditions (Brook et al. 1980). However, some studies identified barite crystals in the water column (McManus et al. 1998, Monnin et al. 1999). Barite formation within the marine environment requires $\mathrm{Ba}$ and $\mathrm{SO}_{4}$ solution interaction and supersaturation for its precipitation and preservation along the water column (Griffith and Paytan 2012). Barite may be primarily precipitated in microenvironments due to the release of $\mathrm{SO}_{4}$ from the degradation of organic matter, and $\mathrm{Ba}$ and $\mathrm{SO}_{4}$ through the dissolution of celestine $\left(\mathrm{SrSO}_{4}\right)$ from organisms enriched in $\mathrm{Ba}$ such as acantharians (protozoan zooplankton) (Fisher et al. 1991, Bernstein et al. 1998).

The barite formation mechanism derived from the degradation of organic matter $(\mathrm{OM})$ is the oxidation of organic sulfur producing $\mathrm{SO}_{4}$ (Griffith and Paytan 2012). This $\mathrm{SO}_{4}$ reacts with $\mathrm{Ba}$ from continental sources, generating a supersaturated microenvironment forming barite which is then deposited in sediments. The formation of barite crystals can be independent of the presence of acantharia and biogenic silica, but it is favored during the decomposition of OM (Griffith and Paytan 2012). The authigenic precipitation of barite dominates over biogenic barite formation in the ocean, as indicated by the low participation of organisms in the direct precipitation of barite (Paytan and Griffith 2007, Griffith and Paytan 2012). Besides these types of barite formation, $\mathrm{Ba}$ is released in cold seeps and by hydrothermal activity on the ocean floor, forming barite upon contact with seawater $\mathrm{SO}_{4}$ (Monnin et al. 1999).

According to Bernstein et al. (1998) acantharians influence the distribution of $\mathrm{Ba}$ in the oceans, although the significance of this individual process as described above is still under debate (Bernstein and Byrne 2004) and not exclusively dependent on the presence of acantharians (Ganeshram et al. 2003). Barite also has been reported in benthic xenophyophores (benthic protozoans), although further studies are required to elucidate whether this is due to actively precipitation or retention during filter feeding (Gooday and Nott 1982, Jacquet et al. 2005). In addition, it has been hypothesized that some protists and algae are capable of intracellular barite precipitation thus maintaining their orientation and depth in the water column by adjusting their density (Tendal 1972). 
Besides acantharians, other planktonic species play an important role on the formation of barite. In a study carried out by Stecher and Kogut (1999) it was reported that, for the period of a spring bloom, dissolved Ba decreased during blooming and returned to its former levels thereafter. The study did not identify whether Ba was absorbed or adsorbed by the organisms. However, the presence of these organisms can generate supersaturated microenvironments during senescence, which could lead to the precipitation of barite (Ganeshram et al. 2003). However, no abundant planktonic group containing intracellular barite crystals was yet identified in the marine environment (Gonzalez-Munoz et al. 2012). This renders the active biological precipitation insignificant part on the total marine barite budget (Paytan and Griffith 2007).

The different types of barite formation in the marine environment are reflected in different crystal sizes and morphologies of barite (Paytan et al. 2002). A powerful approach to identify the different fluids from which the barite crystal precipitated from is to investigate its trace element and isotope geochemistry (Griffith and Paytan 2012).

In sediments, barite remains stable under oxidizing conditions or will be remineralized under reducing conditions. The remineralization of $\mathrm{Ba}$ would be predominantly derived from sedimentary barite which was initially deposited and preserved under oxic conditions. But due to continuous deposition and the decomposition of OM sediments can evolve towards more reducing conditions. The sulfide, generated

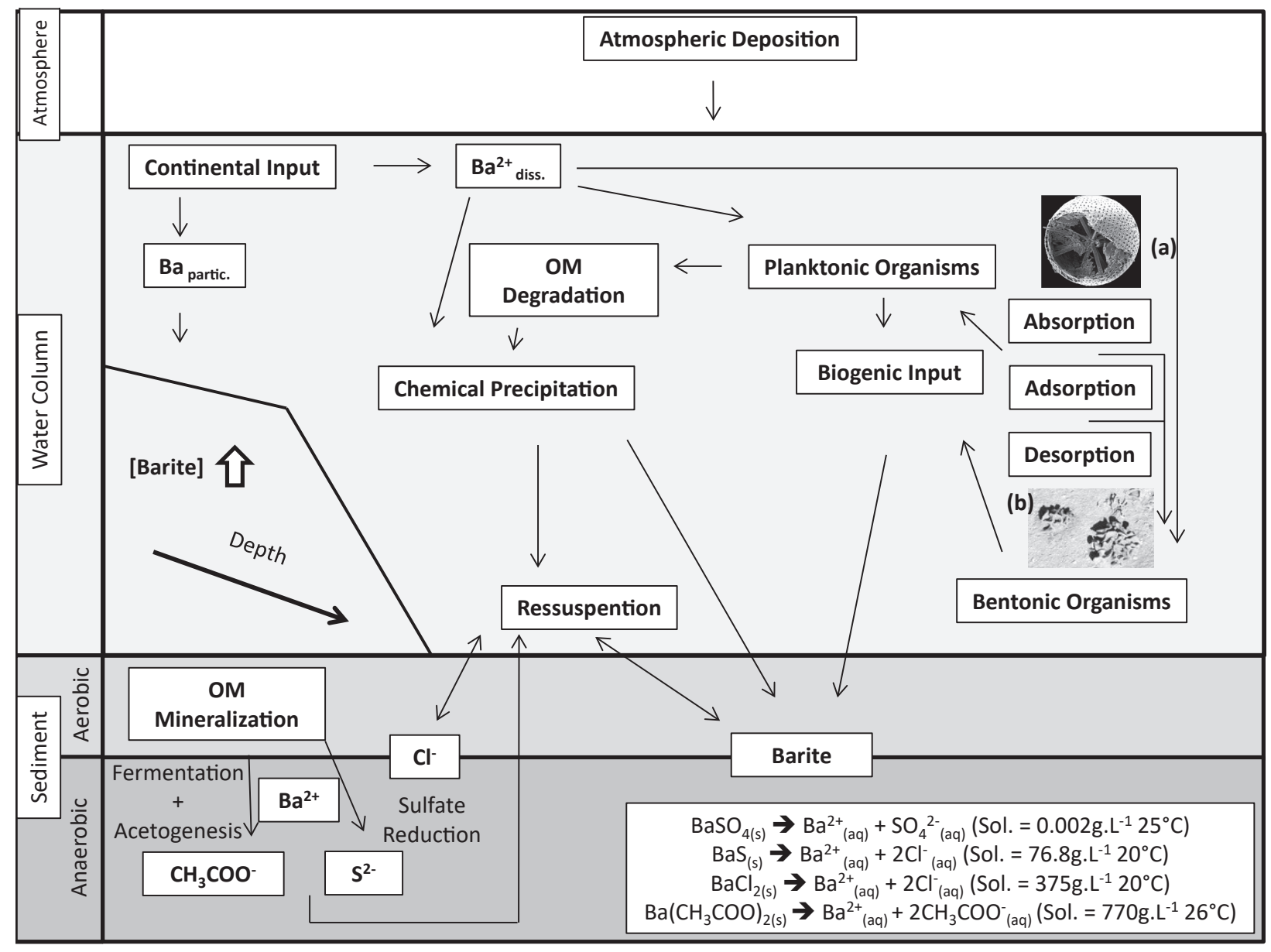

Figure 1 - Barite formation mechanisms along the water column \{Adapted from Monnin et al. (1999)\}. (a - Acantharia illustrating planktonic organisms; b - Xenophyophore representing benthic organisms). 
during $\mathrm{SO}_{4}$ reduction, forms barium sulfide which is highly soluble $\left(76.8 \mathrm{~g} \mathrm{~L}^{-1}\right.$ at $\left.20{ }^{\circ} \mathrm{C}\right)$ this releasing $\mathrm{Ba}$ into the pore water and to the sediment-water interface. This process also releases dissolved $\mathrm{Ba}$ to the water column, which can then be re-precipitated with $\mathrm{SO}_{4}$ forming barite again under oxidizing conditions (diagenetic barite formation)(Dean and Schreiber 1978). In addition, other anions such as chloride (Cl) and acetate $\left(\mathrm{CH}_{3} \mathrm{COO}\right)$ may also be important during such remobilization and post-depositional migration processes. Chloride is one of the most abundant ions in the marine environment and the solubility of barium chloride is high. Due to this high solubility, $\mathrm{Cl}$ and $\mathrm{Ba}$, can be kept in solution, thus allowing its release to the water column. Acetate can in turns originate from the anaerobic decomposition of OM in the metabolic pathway where acetate is converted into methane through hydrolysis, fermentation, acetogenesis, and methanogenesis (Killops and Killops 2004). Because $\mathrm{CH}_{3} \mathrm{COO}$ is generated during the acetogenesis stage, it may be an alternative ligand keeping $\mathrm{Ba}$ in dissolved form.

THE IMPORTANCE OF BA IN (PALEO)PRODUCTIVITY

In the water column, Ba has a nutrient-like distribution indicating a direct or indirect influence of the marine biological cycling as demonstrated by the covariation of Ba abundance and organic carbon and biogenic debris fluxes in this environment (Bishop 1988, Dehairs et al. 1980, 1987, Dymond et al. 1992). The relationship between barite and flux of organic carbon in ocean sediment traps has been used as a potential indicator for (paleo)productivity (Dymond et al. 1992). According to Dymond et al. (1992) there is a strong correlation between particulate organic carbon and $\mathrm{Ba}$ fluxes in different seasons and in different marine environments which, again, suggests a coupling of $\mathrm{Ba}$ to the marine biological cycling. This correlation between $\mathrm{Ba}$ and organic carbon can then be used to compute the marine organic carbon rain reaching the seafloor (Dymond et al. 1992).

According to Dymond et al. (1992), the preservation rate of barite is approximately $30 \%$ and thus higher than other indicators of productivity such as carbonates with approximately $10 \%$, biogenic silica with approximately $5 \%$ and organic carbon with approximately $1 \%$. Barite is therefore a promising proxy for marine (paleo)productivity (Dymond et al. 1992) and can be superior to other approaches when environmental conditions compromise carbonates or bias sedimentation rates (Hull and Norris 2011). For example, calcium isotopes in barite crystals can be a reliable tool to identify changes in seawater temperature over time due to high preservation of barite crystals under oxic conditions (Paytan et al. 1993). On the other hand, calcium isotopes from carbonates can suffer from changes in the temperature and of group of calcifyers that might be affected by climate changes. This bias would not be visible on calcium isotopes from barite records (Griffith et al. 2011).

Nürnberg et al. (1997) concluded that $\mathrm{Ba}_{\text {excess }}$ (considered as the fraction of $\mathrm{Ba}$ that it is not supplied by terrigenous material) is a suitable proxy for productivity in the Southern Ocean, since the $\mathrm{Ba}_{\text {excess }}$ results reflected largely the distribution of biogenic silica production. Some discrepancy can however result from partial silica dissolution in the water column, at the sediment-water interface and/or in the sediments (Nürnberg et al. 1997). Bonn et al. (1998), for example, found some inconsistences in biogenic silica and barite records generated from Southern Ocean sediment cores. As for the interglacial stages, they related this to (partial) dissolution of biogenic silica. In contrast, during the deglaciation they found that the barite record is led by the biogenic silica. Thus environmental conditions can bias sedimentary Ba signals, which for more robust interpretation one should take into consideration the use of at least two independent indicators (Bonn et al. 1998). 
Dymond et al. (1992) proposed a series of steps to determine the flux of Ba related to carbon export and to predict new production (Equation 1) from the excess Ba content (Equation 2-4).

$$
\mathrm{P}_{\text {new }}=\left[\left(\mathrm{F}_{\mathrm{Ba}} 0.171 \mathrm{Ba}^{2.218} \mathrm{Z}^{0.476-0.00478 \mathrm{Ba}}\right) /(2056)\right]^{1.504}
$$

where $\mathrm{F}_{\mathrm{Ba}}$ is the flux of $\mathrm{Ba}$ (corrected for $\mathrm{Ba}$ associated to aluminosilicates - thus $\mathrm{Ba}_{\text {excess }}$ ); $\mathrm{Ba}$ is the dissolved $\mathrm{Ba}$ concentration; $\mathrm{z}$ is the water depth. This is an attempt to estimate the productivity from $\mathrm{Ba}$ accumulation rates in marine sediments (Dymond et al. 1992).

The algorithm for excess $\mathrm{Ba}$ determination takes into consideration the barite concentration by calculating the difference between total $\mathrm{Ba}\left(\mathrm{Ba}_{\text {total }}\right)$ and the terrigenous $\mathrm{Ba}\left(\mathrm{Ba}_{\text {terrigenous }}\right)$ concentration of sediments which would be associated with terrigenous aluminosilicates (Equation 2).

$$
\mathrm{Ba}_{\text {excess }}=\mathrm{Ba}_{\text {total }}-\mathrm{Ba}_{\text {terrigenous }}
$$

Terrigenous barium is calculated (Equation 3) by multiplying the $\mathrm{Al}_{\text {total }}$ fraction with the $(\mathrm{Ba} / \mathrm{Al})_{\text {detrital }}$ ratio.

$$
\mathrm{Ba}_{\text {terrigenous }}=\mathrm{Al}_{\text {total }} \times(\mathrm{Ba} / \mathrm{Al})_{\text {detrital }}
$$

The $(\mathrm{Ba} / \mathrm{Al})_{\text {detrital }}$ ratio is a crucial part of this equation because it is obtained through direct and indirect methods and would allow the direct relation to export productivity. From the two equations above (equations 2 and 3) a fourth equation is obtained (Equation 4).

$$
\mathrm{Ba}_{\text {excess }}=\mathrm{Ba}_{\text {total }}-\left(\mathrm{Al}_{\text {total }} \times(\mathrm{Ba} / \mathrm{Al})_{\text {detrital }}\right)
$$

The results of total Titanium can be used in the same way as $\mathrm{Al}_{\text {total }}$, because both elements are conservative, stable, and indicators of terrigenous contribution (Klump et al. 2000). It is noted that Al can be associated with other authigenic sedimentary phases and be present in diatoms tests (Dixit et al. 2001) and titanium normalization can be compromised in areas where volcanic activity is present due to dust input (Murray and Leinen 1996). The two tracers would result in values close to barite content (Reitz et al. 2004). However, studies using Al are commonly found in the literature, a fact which facilitates comparison of studies among on another (Reitz et al. 2004, Schenau et al. 2001).

The terrigenous $\mathrm{Ba} / \mathrm{Al}$ ratio for the determination of the excess of $\mathrm{Ba}$ can be obtained using crust composition values from sedimentary rocks, with an established value of 0.0075 as suggested by Dymond et al. (1992). This method is known as indirect or normative and is based on pre-established ratios. But these values can introduce errors for sedimentary environments that receive large quantities of detrital matter and disregard the differences associated with the biota and the geochemical composition of each region (Reitz et al. 2004). According to Dymond et al. (1992) the uncertainty, for samples with 30\% detrital $\mathrm{Ba}$, would be of $\pm 15 \%$ error; and a factor of 10 if the samples have $75 \%$ detrital $\mathrm{Ba}$. These uncertainties can be reduced if the detrital $\mathrm{Ba}$ component in sediments is analyzed. The ratios between authigenic and terrigenous $\mathrm{Ba}$ are highly variable in continental margins as the input of terrigenous material is higher than open ocean environment (McManus et al. 2002).

Some studies Gonneea and Paytan (2006), Rutten and de Lange (2002), Snyder et al. (2007) used predetermined ratios from samples collected directly from inland drainage basin or major river deposits that produce representative results of the local terrigenous composition for Ba. Such values are representative of the terrigenous background geochemistry and thus more appropriate to use for the calculation of $\mathrm{Ba}_{\text {excess }}$ in marine sediments than average crust values (Klump et al. 2000). 
TABLE I

Study matrix analyzed and Ba detection techniques for abiotic samples.

\begin{tabular}{|c|c|c|}
\hline Matrix & Detection Technique & Reference \\
\hline Sediment* & ICP-AES & Fagel et al. (2002), McManus et al. (2002), Sanchez-Vidal et al. (2005) \\
\hline Sediment* & ICP-MS & $\begin{array}{c}\text { Fagel et al. (1999), Kasten et al. (2001), Sato et al. (2002), } \\
\text { Hernandez-Sanchez et al. (2011) }\end{array}$ \\
\hline Sediment* & ID-ICP-MS & McManus et al. (2002) \\
\hline Sediment* & SEM & Robin et al. (2003) \\
\hline Sediment* & $\mathrm{XRF}$ & Pirrung et al. (2008), Prakash Babu et al. (2002) \\
\hline Sediment** & ICP-AES & $\begin{array}{l}\text { Schenau et al. (2001), Rutten and de Lange (2002), Reitz et al. (2004), } \\
\text { Plewa et al. (2006), Snyder et al. (2007), Saizhang et al. (2013) }\end{array}$ \\
\hline Sediment** & ICP-MS & Henkel et al. (2012) \\
\hline Sediment** & ICP-OES & Gonneea and Paytan (2006), Hendy (2010), Veguería et al. (2002) \\
\hline Sediment** & SEM & Eagle et al. (2003), Paytan et al. (2002), Henkel et al. (2012) \\
\hline Sediment** & XRD & Paytan et al. (2002) \\
\hline Sediment** & XRD - SEM - EDS & Paytan et al. (1993) \\
\hline Sediment*** & ICP-AES & Klump et al. (2000), Pfeifer et al. (2001) \\
\hline Sediment $* * *$ & XRD & Jacquet et al. (2008) \\
\hline SPM* & ICP-AES & Jeandel et al. (2000), Jacquet et al. (2007) \\
\hline SPM* & ICP-MS & $\begin{array}{c}\text { Fagel et al. (1999), Jeandel et al. (2000), Jacquet et al. (2007), } \\
\text { Dehairs et al. (2008) }\end{array}$ \\
\hline SPM* & INAA/ICP-OES & Francois et al. (1995) \\
\hline Water & AAS & Riedinger et al. (2006) \\
\hline
\end{tabular}

* Barite was determined through normalization of total $\mathrm{Al}$ or Ti, obtained with crust averages.

** Barite determination through sequential extraction method.

*** Barite values from $\mathrm{Al}$ or Ti concentrations determined in sediments of tributary rivers from the study area.

ICP-AES - Inductively Coupled Plasma Atomic Emission Spectrometry, ICP-MS - Inductively Coupled Plasma Mass Spectrometry, ID-ICP-MS - Isotope Dilution Inductively Coupled Plasma Mass Spectrometry, SEM - Scanning Electron Microscope, XRF - X-Ray Fluorescence, ICP-OES - Inductively Coupled Plasma Optical Emission Spectrometry, XRD - X-Ray Diffraction, EDS -Energy. Dispersive X-Ray Spectroscopy, INAA - Instrumental Neutron Activation Analysis, AAS - Atomic Absorption Spectroscopy.

The sequential extraction methodology is a technique in which leaching of the sediment with a series of selective extraction solutions is performed in order to reach fractions of interest for analysis (Tessier et al. 1979). According to these authors, this technique provides information about the source, mobility, bioavailability, and physical chemistry, as well as the mode of occurrence and transport of trace elements in general. As in the work of Tessier et al. (1979), the sequential extraction technique was used to determine generalized associations of various trace elements with different geochemical supports. That same technique was later used with improvements that made it more selective for the study of barite. One of the methods used was initially developed for the determination of phosphorus (Schenau and de Lange 2000). From this study other authors, have adopted the methodology of sequential extraction, thus determining the associated phases of Ba (Plewa et al. 2006, Reitz et al. 2004, Saizhang et al. 2013).

Among the sequential extraction methodologies designed for the determination of $\mathrm{Ba}$ and its associations, certain exceptional examples from the literature will be briefly mentioned: (a) The four-step proposal by Schenau et al. (2001), modified by Plewa et al. (2006), Reitz et al. (2004) and Saizhang et al. (2013); (b) A five-stage method for the selective extraction of Ba-bearing phases (Paytan et al. 1993). This method has been widely applied for the determination of barite. It uses X-ray diffraction and scanning 
electron microscopy (Paytan et al. 1993). This procedure preserves barite until the end of the sequential extraction so that it can be screened and determined under a microscope. Otherwise, the final residue can be dissolved and analyzed following one of the techniques summarized in Table I in order to determine the concentration of Ba that would lead to barite (Paytan et al. 1993, Eagle et al. 2003); (c) Rutten and de Lange (2002) suggest a method composed of 12 steps. For some phases they use the same extractor, but with different $\mathrm{pH}$ values (Rutten and de Lange 2002). In addition, among the 12 steps proposed by these authors, three of are equal to those of Schenau et al. (2001) (first method mentioned above); (d) Snyder et al. (2007) proposed the use of aqua-regia, i.e. a mixture of concentrated $\mathrm{HCl}$ and $\mathrm{HNO}_{3}$ acids dissolving barite at a rate of $1 \mathrm{mg} \mathrm{mL}^{-1}$. Whereas, siliciclastic material, i.e. the fraction of the aluminosilicate, does not dissolve and remains in the residue; e) Veguería et al. (2002), on the other hand, suggest an extraction with only one phase which uses the addition of a mixed solution composed of $0.1 \mathrm{M} \mathrm{Na}_{2}$-EDTA and $0.5 \mathrm{M} \mathrm{NH}_{4} \mathrm{OH}$ which would selectively solubilize the barite present in the sediment.

The determination of barite content may be performed with various direct and quantitative methods either directly in sediment samples using X-ray diffraction (Paytan et al. 1993, Pirrung et al. 2008, Rutten and de Lange 2002), sequential extraction (Reitz et al. 2004), or indirectly with pre-determined values of $\mathrm{Ba} / \mathrm{Al}$ content from terrigenous sources. The use of X-ray diffraction and scanning electron microscopy after sequential leaching allows direct determination of the barite content (Paytan et al. 1993). The sequential extraction method allows the direct determination of barite contained in sediments and $(\mathrm{Ba} / \mathrm{Al})_{\text {detrital }}$ ratio. This method takes into consideration the environmental and geologic factors of the site without including the errors associated with different sedimentary environments, thus generating satisfactory results (Eagle et al. 2003, Gonneea and Paytan 2006, Paytan et al. 1993, Plewa et al. 2006, Reitz et al. 2004, Rutten and de Lange 2002, Saizhang et al. 2013, Schenau et al. 2001) and it is an alternative to a more expensive method although more time demanding.

The detrital $\mathrm{Ba} / \mathrm{Al}$ ratio is influenced by the composition of the source material, thus the use of values taken from literature can underestimate or overestimate $\mathrm{Ba}_{\text {excess }}$. Reitz et al. (2004) found that, when normalized to the average crust values, sediment samples from Pacific and Atlantic Oceans differed significantly from the results obtained with the sequential extraction method. The same pattern was observed in sediments from Campos Basin (Rio de Janeiro) where various ratios were used to obtain $\mathrm{Ba}_{\text {excess }}$ values (Liguori 2014). Liguori (2014) showed that the $\mathrm{Ba} / \mathrm{Al}$ ratios of the local river sediments and the average crust value do not reliably represent the $\mathrm{Ba} / \mathrm{Al}$ of the marine sediments. And, therefore, the use of sequential extraction is the best way to determine $\mathrm{Ba}_{\text {excess }}$.

Pfeifer et al. (2001) used the average crust ratios of 0.0075 and 0.0067 as proposed by Dymond et al. (1992) and Nürnberg et al. (1997), respectively. Using these ratios for sediments of the South Atlantic Ocean in south of Brazil (Porto Alegre area) and the Argentine Basin resulted in incorrect, overly negative values for $\mathrm{Ba}_{\text {excess }}$. However, positive values were obtained through the use of a $\mathrm{Ba} / \mathrm{Al}_{\text {detrital }}$ ratio of 0.004 determined for sediments from the same region north of $30^{\circ} \mathrm{S}$ by Gingele and Dahmke (1994). Thus, the use of sequential extraction methods is recommended to obtain valid concentration values for barite in areas with pronounced detrital input. It is noted that this approach is critical in particular for sediments with more than $40 \%$ detrital Ba composition (Klump et al. 2000). Moreover, the excess Ba tool should be used with caution in areas with high terrigenous input (McManus et al. 2002). Similarly, the interpretation of paleo $\mathrm{Ba}_{\text {excess }}$ data in terms of productivity requires thorough consideration of the full range of potential Ba-bearing phases in the sediments (Gonneea and Paytan 2006, Saizhang et al. 2013). 
However, when calculating the excess Ba by the direct method using sequential extraction, all phases, except the aluminosilicate phase, are considered related to productivity. This could generate errors that are difficult to assess, especially when the fraction of $\mathrm{Ba}$ associated with oxy-hydroxides, which is not related to productivity, is pronounced and the objective of the study is to reconstruct past productivity (Gonneea and Paytan 2006). In addition, barite is not preserved in anoxic environments where sulfate reduction occurs and is released to the pore waters. Potentially, if Ba reaches an oxic layer of the sediment it can however precipitate as barite again (diagenetic barite). This type of barite formation is not related to carbon export (Paytan et al. 2002) and would not be suitable for (paleo)productivity studies (Dymond et al. 1992).

In order to use $\mathrm{Ba}$ as a proxy and correlate it with (paleo)productivity it is recommended to avoid sulfate reducing environments and to verify first for the formation of diagenetic barite. According to Paytan et al. (2002) the isotopic composition of sulfur and crystal morphologies of barite minerals can be assessed in order to differentiate the types of barite formation in the water column. In case of diagenetic formation of barite this proxy cannot be reliable for the study. The use of $\mathrm{Ba}_{\text {excess }}$ as a proxy for (paleo)productivity require hence some important information: a) the amount of Ba contributing to the barite formation, b) the source of $\mathrm{Al}$ or $\mathrm{Ti}, \mathrm{c}$ ) accurate determination of $\mathrm{Ba} / \mathrm{Al}$ and/or Ba/Ti ratios (Dymond et al. 1992, Paytan and Griffith 2007).

\section{CONCLUSIONS}

Barite in the marine environment has been used as a promising (paleo)productivity proxy due to its high preservation rate under oxic conditions, which is higher than other productivity proxies such as carbonates and organic carbon. The formulation of algorithms to reconstruct (paleo)productivity with the use of barite, as $\mathrm{Ba}_{\text {excess }}$, progressed significantly as the analytical techniques improved and as more information becomes available on the formation of barite in the water column. However, Ba can be associated with various biogeochemical phases and is not exclusively present as barite in the water column. Moreover, barite can be mobile in the sediment column as it is remineralized under anoxic conditions, but might reprecipitate under oxic conditions. This formation process is not related to productivity and can thus bias the interpretation of $\mathrm{Ba}_{\text {excess }}$ as a productivity indicator. In order to avoid that problem, one can use $\mathrm{Ba}$ and sulfur isotopes and/or the crystallography of the mineral to track their formation. A better understanding on barite formation and its preservation can then help to fully exploit this geochemical proxy as a tool in paleoceanographic and hydrogeological research.

\section{ACKNOWLEDGMENTS}

The authors are grateful to the Laboratório de Ciências Ambientais of the Centro de Biociências e Biotecnologia at the Universidade Estadual do Norte Fluminense for the use of its infrastructure. Thanks are also extended to Instituto Nacional de Ciência e Tecnologia de Transferência de Materiais ContinenteOceano (INCT-TMCOcean) and Conselho Nacional de Desenvolvimento Científico e Tecnológico (CNPq: 573.601/08-9). C.E. Rezende received financial support from CNPq (506.750/2013-2) and Fundação Carlos Chagas Filho de Amparo à Pesquisa do Estado do Rio de Janeiro ( FAPERJ, E-26/110.032/2011).

\section{REFERENCES}

BERNSTEIN RE AND BYRNE RH. 2004. Acantharians and marine barite. Mar Chem 86: 45-50. 
BERNSTEIN RE, BYRNE RH AND SCHIJF J. 1998. Acantharians: a missing link in the oceanic biogeochemistry of barium. Deep-Sea Res Pt I 45: 491-505.

BISHOP JKB. 1988. The barite-opal-organic carbon association in oceanic particulate matter. Nature 332: 341-344.

BONN WJ, GINGELE FX, GROBE H, MACKENSEN A AND FFITTERER DK. 1998. Palaeoproductivity at the Antarctic continental margin: opal and barium records for the last 400 ka. Palaeogeogr Palaeocl 139: 195-211.

BROOK A, FOTHERINGHAM A, BRADLY J AND JENKINS A. 1980. Barium accumulation by desmids of the genus Closterium (Zygnemaphyceae). Brit Phycol J 15: 261-264.

CHOW TJ AND GOLDBERG ED. 1960. On the marine geochemistry of barium. Geochim Cosmochim Ac 20: $192-198$.

COFFEY M, DEHAIRS F, COLLETTE O, LUTHER G, CHURCH T AND JICKELLS T. 1997. The Behaviour of Dissolved Barium in Estuaries. Estuar Coast Shelf S 45: 113-121.

DEAN W AND SCHREIBER BC. 1978. Authigenic barite, leg 41 deep sea drilling project. Proc. ODP, Init. Repts, p. 105-112.

DEHAIRS F, CHESSELET R AND JEDWAB J. 1980. Discrete Suspended Particles Of Barite And The Barium Cycle In The Open Ocean. Earth Planet Sc Lett 49: 528-550.

DEHAIRS F ET AL. 2008. Barium in twilight zone suspended matter as a potential proxy for particulate organic carbon remineralization: Results for the North Pacific. Deep-Sea Res Pt II 55: 1673-1683.

DEHAIRS F, LAMBERT C, CHESSELET R AND RISLER N. 1987. The biological production of marine suspended barite and the barium cycle in the Western Mediterranean Sea. Biogeochemistry 4: 119-139.

DIXIT S, VAN CAPPELLEN P AND VAN BENNEKOM AJ. 2001. Processes controlling solubility of biogenic silica and pore water build-up of silicic acid in marine sediments. Mar Chem 73: 333-352.

DYMOND J, SUESS E AND LYLE M. 1992. Barium In Deep-Sea Sediment: A Geochemical Proxy For Paleoproductiv1ty. Paleoceanography 7: 163-181.

EAGLE M, PAYTAN A, ARRIGO KR, VAN DIJKEN G AND MURRAY RW. 2003. A comparison between excess barium and barite as indicators of carbon export. Paleoceanography 18: 1-13.

FAGEL N, ANDRÉ L AND DEHAIRS F. 1999. Advective excess Ba transport as shown from sediment and trap geochemical signatures. Geochim Cosmochim Ac 63: 2353-2367.

FAGEL N, DEHAIRS F, ANDRÉ L, BAREILLE G AND MONNIN C. 2002. Ba distribution in surface Southern Ocean sediments and export production estimates. Paleoceanography 17: 1-20.

FISHER NS, GUILLARD RRL AND BANKSTON DC. 1991. The accumulation of barium by marine phytoplankton grown in culture. J Mar Res 49: 339-354.

FRANCOIS R, HONJO S, MANGANINI SJ AND RAVIZZA GE. 1995. Biogenic barium fluxes to the deep sea: Implications for paleoproductivity reconstruction. Global Biogeochem Cy 9: 289-303.

GANESHRAM RS, FRANCOIS R, COMMEAU J AND BROWN-LEGER SL. 2003. An experimental investigation of barite formation in seawater. Geochim Cosmochim Ac 67: 2599-2605.

GINGELE FX AND DAHMKE A. 1994. Discrete barite particles and barium as tracers of paleoproductivity in South Atlantic sediments. Paleoceanography 9: 151-168.

GOODAY AJ AND NOTT JA. 1982. Intracellular barite crystals in two Xenophyaphores, Aschemonella ramuliformis and Galatheammina sp. with comments on the taxonomy of A. ramuliformis. J Mar Biol Assoc UK 62: 595-605.

GONNEEA ME AND PAYTAN A. 2006. Phase associations of barium in marine sediments. Mar Chem 100: 124-135.

GONZALEZ-MUNOZ MT, MARTINEZ-RUIZ F, MORCILLO F, MARTIN-RAMOS JD AND PAYTAN A. 2012. Precipitation of barite by marine bacteria: A possible mechanism for marine barite formation. Geology 40: 675-678.

GRIFFITH EM AND PAYTAN A. 2012. Barite in the ocean - occurrence, geochemistry and palaeoceanographic applications. Sedimentology 59: 1817-1835.

GRIFFITH EM, PAYTAN A, EISENHAUER A, BULLEN TD AND THOMAS E. 2011. Seawater calcium isotope ratios across the Eocene-Oligocene transition. Geology 39: 683-686.

GUICHARD F, CHURCH TM, TREUIL M AND JAFFREZIC H. 1979. Rare earths in barites: distribution and effects on aqueous partitioning. Geochim Cosmochim Ac 43: 983-997.

HANOR JS AND CHAN LH. 1977. Non-conservative behavior of barium during mixing of Mississippi river and Gulf of Mexico waters. Earth Planet Sc Lett 37: 242-250.

HENDY IL. 2010. Diagenetic behavior of barite in a coastal upwelling setting. Paleoceanography 25: 1-9.

HENKEL S ET AL. 2012. Diagenetic barium cycling in Black Sea sediments - A case study for anoxic marine environments. Geochim Cosmochim Ac 88: 88-105.

HERNANDEZ-SANCHEZ MT, MILLS RA, PLANQUETTE H, PANCOST RD, HEPBURN L, SALTER I AND FITZGEORGEBALFOUR T. 2011. Quantifying export production in the Southern Ocean: Implications for the Ba xs proxy. Paleoceanography 26: 1-19. 
HULL PM AND NORRIS RD. 2011. Diverse patterns of ocean export productivity change across the Cretaceous- Paleogene boundary: new insights from biogenic barium. Paleoceanography 26: 1-10.

JACQUET SHM, DEHAIRS F, CARDINAL D, NAVEZ J AND DELILLE B. 2005. Barium distribution across the Southern Ocean frontal system in the Crozet-Kerguelen Basin. Mar Chem 95: 149-162.

JACQUET SHM, HENJES J AND DEHAIRS F. 2007. Particulate Ba-barite and acantharians in the Southern Ocean during the European Iron Fertilization Experiment (EIFEX). J Geophys Res 112: 1-28.

JACQUET SHM, SAVOYE N, DEHAIRS F, STRASS VH AND CARDINAL D. 2008. Mesopelagic carbon remineralization during the European iron fertilization experiment. Global Biogeochem Cy 22: 1-9.

JEANDEL C, TACHIKAWA K, BORY A AND DEHAIRS F. 2000. Biogenic barium in suspended and trapped material as a tracer of export production in the tropical NE Atlantic (EUMELI sites). Mar Chem 71: 125-142.

KASTEN S, HAESE RR, ZABEL M, RÜHLEMANN C AND Schulz HD. 2001. Barium peaks at glacial terminations in sediments of the equatorial Atlantic Ocean-relicts of deglacial productivity pulses? Chem Geol 175: 635-651.

KILLOPS S AND KILLOPS V. 2004. Introduction to Organic Geochemistry. Malden, MA USA: Blackwell Publishing Ltd., 393 p.

KLUMP J, HEBBELN D AND WEFER G. 2000. The impact of sediment provenance on barium-based productivity estimates. Mar Geol 169: 259-271.

LIGUORI BTP. 2014. Fracionamento Geoquímico do Bário em Sedimentos Superficiais da Margem Continental Sudeste Brasileira, Bacia de Campos, RJ. Master Thesis. (Unpublished).

MCMANUS J ET AL. 1998. Geochemistry of barium in marine sediments: Implications for its use as a paleoproxy. Geochim Cosmochim Ac 62: 3453-3473.

MCMANUS J, DYMOND J, DUNBAR RB AND COLLIER RW. 2002. Particulate barium fuxes in the Ross Sea. Mar Geol 184: $1-15$.

MONNIN C, JEANDEL C, CATTALDO T AND DEHAIRS F. 1999. The marine barite saturation state of the world's oceans. Mar Chem 65: 253-261.

MURRAY RW AND LEINEN M. 1996. Scavenged excess aluminum and its relationship to bulk titanium in biogenic sediment from the central equatorial Pacific Ocean. Geochim Cosmochim Ac 60: 3869-3878.

NÜRNBERG CC, BOHRMANN G, SCHLUTER M AND FRANK M. 1997. Barium accumulation in the Atlantic sector of the Southern Ocean: Results from 190,000-year records. Palaeogeography 12: 594-603.

PAYTAN A AND GRIFFITH EM. 2007. Marine barite: Recorder of variations in ocean export productivity. Deep-Sea Res Pt II 54: 687-705.

PAYTAN A, KASTNER M, MARTIN EE, MACDOUGALL JD AND HERBERT T. 1993. Marine Barite as a monitor of sewater strotium isotope composition. Nature 366: 445-449.

PAYTAN A, MEARON S, COBB K AND KASTNER M. 2002. Origin of marine barite deposits: Sr and S isotope characterization. Geology 30: 747-750.

PFEIFER K, KASTEN S, HENSEN C AND SCHULZ HD. 2001. Reconstruction of primary productivity from the barium contents in surface sediments of the South Atlantic Ocean. Mar Geol 177: 13-24.

PIRRUNG M, ILLNER P AND MATTHIESSEN J. 2008. Biogenic barium in surface sediments of the European Nordic Seas. Mar Geol 250: 89-103.

PLEWA K, MEGGERS H AND KASTEN S. 2006. Barium in sediments off northwest Africa: A tracer for paleoproductivity or meltwater events? Paleoceanography 21: 1-15.

PRAKASH BABU C, BRUMSACK HJ, SCHNETGER B AND BOTTCHER ME. 2002. Barium as a productivity proxy in continental margin sediments: a study from the eastern Arabian Sea. Mar Geol 184: 189-206.

RIEDINGER N, KASTEN S, GRÖGER J, FRANKE C AND PFEIFER K. 2006. Active and buried authigenic barite 469 fronts in sediments from the Eastern Cape Basin. Earth Planet Sc Lett 241: 876-887.

REITZ A, PFEIFER K, DE LANGE G AND KLUMP J. 2004. Biogenic barium and the detrital Ba/Al ratio: a comparison of their direct and indirect determination. Mar Geol 204: 289-300.

ROBIN E, RABOUILLE C, MARTINEZ G, LEFEVRE I, REYSS J, VAN BEEK P AND JEANDEL C. 2003. Direct barite determination using SEM/EDS-ACC system: implication for constraining barium carriers and barite preservation in marine sediments. Mar Chem 82: 289-306.

RUTTEN A AND DE LANGE G. 2002. A novel selective extraction of barite, and its application to eastern Mediterranean sediments. Earth Planet Sc Lett 198: 11-28.

SAIZHANG TAN, PEISONG YU, CHUANYU HU, ZHENGBING HAN AND HAISHENG Z. 2013. Concentrations and distribution of biogenic barium in surface sediments of Prydz Bay, Antarctica. Advances in Polar Science 24: 153-157.

SANCHEZ-VIDAL A, COLLIER RW, CALAFAT A, FABRES J AND CANALS M. 2005. Particulate barium fluxes on the continental margin: a study from the Alboran Sea (Western Mediterranean). Mar Chem 93: 105-117. 
SATO MM, HISASHI N AND SHIZUO T. 2002. Barium increasing prior to opal during the last termination of glacial ages in the Okhotsk Sea sediments. J Oceanogr 58: 461-467.

SCHENAU SJ AND DE LANGE G. 2000. A novel chemical method to quantify fish debris in marine sediments. Limnol Oceanogr 45: 963-971.

SCHENAU SJ, PRINS MA, DE LANGE G AND MONNIN C. 2001. Barium accumulation in the Arabian Sea : Controls on barite preservation in marine sediments. Geochem Geophys 65: 1545-1556.

SNYDER GT, DICKENS GR AND CASTELLINI DG. 2007. Labile barite contents and dissolved barium concentrations on Blake Ridge: New perspectives on barium cycling above gas hydrate systems. J Geochem Explor 95: 48-65.

STECHER III HA AND KOGUT MB. 1999. Rapid barium removal in the Delaware estuary. Geochim Cosmochim Ac 63: 10031012.

TENDAL OS. 1972. A Monograph of the Xenophyophoria (Rhizopodea, Protozoa). Galathea Reports 12: 7-99.

TESSIER A, CAMPBELL PGC AND BISSON M. 1979. Sequential extraction procedure for the speciation of particulate trace metals. Anal Chem 51: 844-851.

VEGUERÍA SJ, GODOY JM AND MIEKELEY N. 2002. Environmental Impact in Sediments and Seawater due to Discharges of $\mathrm{Ba},{ }^{226} \mathrm{Ra},{ }^{228} \mathrm{Ra}, \mathrm{V}, \mathrm{Ni}$ and $\mathrm{Pb}$ by Produced Water from the Bacia de Campos Oil Field Offshore Platforms. Environ Forensics 3: $115-123$. 